\title{
Biological Soil Crusts and Extremophiles Adjacent to Native Plants at Sabkhas and Rawdahs, Qatar: The Possible Roles
}

\author{
Roda Fahad Al-Thani, Bassam Taha Yasseen* \\ Email address: \\ ralthani@qu.edu.qa (R. F. Al-Thani), bassam_tahaa@yahoo.co.uk (B. T. Yasseen) \\ ${ }^{*}$ Corresponding author
}

Department of Biological and Environmental Sciences, College of Arts \& Sciences, Qatar University, Doha, the State of Qatar

\section{To cite this article:}

Roda Fahad Al-Thani, Bassam Taha Yasseen. Biological Soil Crusts and Extremophiles Adjacent to Native Plants at Sabkhas and Rawdahs, Qatar: The Possible Roles. Frontiers in Environmental Microbiology. Vol. 4, No. 2, 2018, pp. 55-70. doi: 10.11648/j.fem.20180402.13

Received: February 1, 2018; Accepted: February 25, 2018; Published: March 21, 2018

\begin{abstract}
Several studies have investigated the biology of native plants (halophytes and xerophytes), biological soil crusts (BSC), as well as the associated and adjacent microorganisms. These studies concentrated on their eco-physiological aspects as well as the possible roles they might play in various life activities and industries. This article presents the mechanisms adopted by these living organisms to cope with the harsh environment, and the possible roles microorganisms might play to support native plants, some important examples from the flora of Qatar are presented to show these mechanisms. Special attention has been paid to the senescence and death of leaves or whole plants, since this strategy has been considered as an important option for escaping extreme environmental conditions. Discussion about solute accumulation (organic and inorganic) in all native living organisms in general and in microorganisms in particular, could result to further investigation to clarify their roles in such an ecosystem. Some case studies have been reported to discuss the ecological aspects at two main types of habitats in Qatar; Rawdahs and Sabkhas were chosen to show how native living organisms adapt in these habitats. This study discussed the general identification of BSC and microorganisms, as well as their possible roles in the soil biota. The possible methods and mechanisms exhibited by extremophiles to support native plants in coping with saline and arid lands have also been reported in this article. This study also discussed the recent outlook about the origin of metabolic activities in these living organisms to support the growth of native plants under stress conditions.
\end{abstract}

Keywords: Biological Soil Crust, Extremophiles, Halophytes, Adaptation, Microorganisms Role, Horizontal Transfer Gene (HTG)

\section{Introduction}

The State of Qatar is a small country located at the middle of the western part of the Arabian Gulf, it is an extension from the Arabia desert. It covers an area of $11,437 \mathrm{~km}^{2}$, measuring 180 $\mathrm{km}$ long and $85 \mathrm{~km}$ wide, and is situated between $24^{\circ} 27^{\prime}$ and $26^{\circ} 10^{\prime}$ north and at $50^{\circ} 45^{\prime}$ and $51^{\circ} 40^{\prime}$ east. Qatar is surrounded on three sides by the Arabian Gulf, and only the south of Qatar has an extension with the land of Saudi Arabia (Figure 1). The land of Qatar is characterized as flat to wavy, sandy soil is common in the northeastern coastline area while rocky hills and sand dunes are common in the southern parts with a saline coastline and patches of Sabkhas and Rawdahs at many other locations across the country.
This country has no rivers and lakes, hence ground water is the primary source of fresh water. As such, the soil is vulnerable to more desertification and salinization, receives very little rainfall as the annual rainfall may be below 80 $\mathrm{mm}$, ECe may reach above $200 \mathrm{dSm}^{-1}$ for various reasons, and temperatures may exceed $50^{\circ} \mathrm{C}$ during summer. Thus, the climate of this region is considered as warm and humid throughout the year and the land is arid or semi-arid with highly saline soils [1]. The physiography of the State of Qatar is based on a number of studies which started in the mid-seventies of the last century [2, 3] and recognized at least seven regions and soil types: (1) Rocky desert, (2) Rawdahs, (3) Sabkhas, (4) Sand formations, (5) Intertidal areas, (6) Islands, and (7) Cultivated lands. 


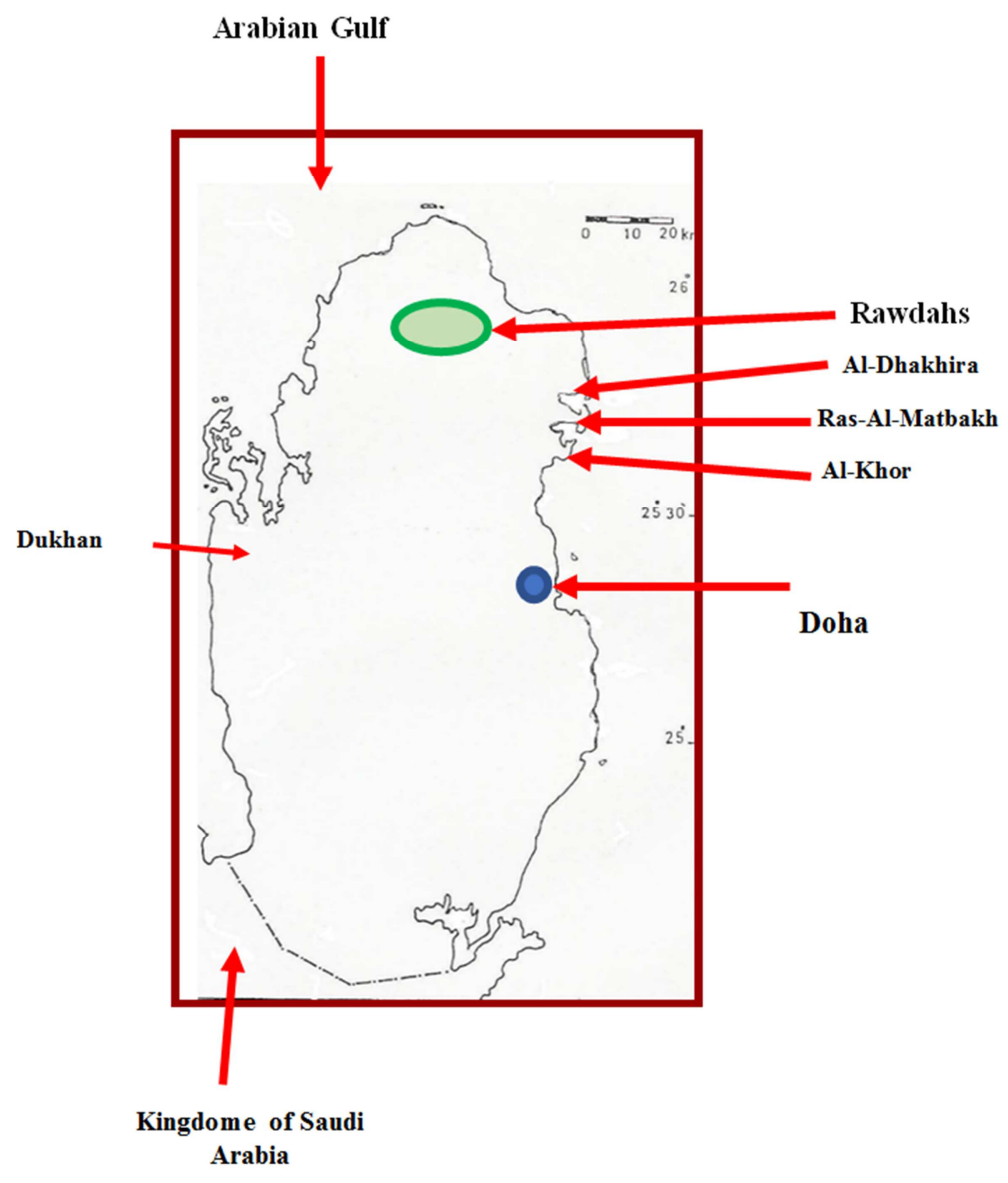

Figure 1. Map of Qatar showing the main locations of case studies.

This article concentrated mainly on two extremes of these regions:

First: Rawdahs represent the area with good quality of water and soil, and are found normally in the northern half of the country. There are about 850 surface depressions (Rawdahs) in Qatar, which are produced as a result of the collapse in the earth surface below and / or as a result of evaporation from the soil surface [4]. The area of each Rawdah ranged from a few square hundred meters to three square kilometers, and circular in shape and lie up to $20 \mathrm{~m}$ below the surrounding landscape. Soils in Rawdahs are enriched with calcareous loams, clay loams, silt and often interspersed with sand and minerals that are washed down from the surrounding higher areas during rainy seasons, and therefore, are considered as good rangelands and can be transformed into farmlands as well as lands for the grazing of camels and cattle.

Second: Sabkhas are salt flats (or salt pans) and are the most prominent feature of the Arabian Gulf region; it might be vegetated or barren. They are characterized by high soil salinity, and encompass most halophytes and extremophiles which have different mechanisms to deal with such highly saline and arid lands. Most halophytic plants are well adapted and inhabit in such an ecosystem; however, other halophytic taxa might not be able to cope with Sabkhas, thereby leaving Sabkhas barren (Figure 2). Most studies were conducted in sabkhas in the eastern coast from Doha city northwards to Al-Khor, Ras-Al-Matbakh, Al-Dhakhira and some Rowdahs in the mid-land of northern Qatar (Figures 1, 3), which concentrate on the eco-physiological aspects of halophytic plants and Halo-thermophilic microorganisms. More discussions and elucidations can be obtained from research books [5], and several published articles [6-12].

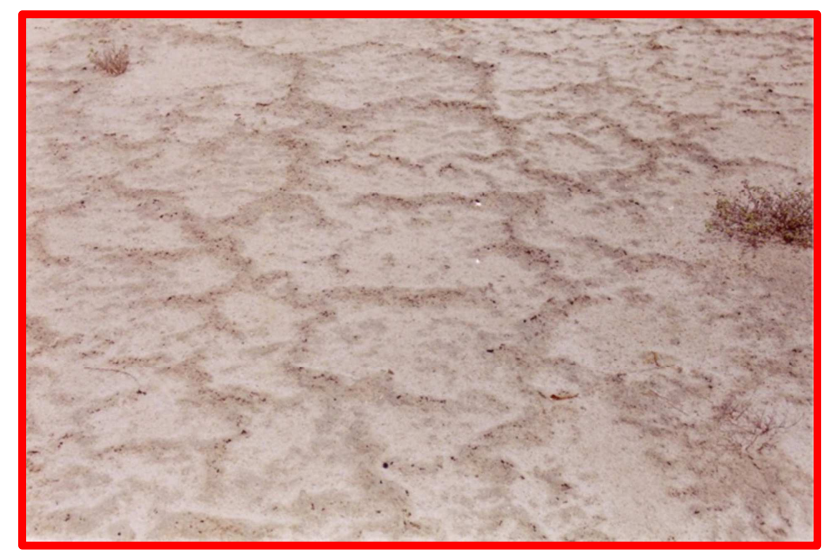

Figure 2. Soils at Sabkhas could become barren. Very few plants can survive arid lands and high saline soils.

It has been reported that numerous Sabkhas in Qatar cover about $7 \%$ of the land surface [13], and occupy a total area of 701 square kilometers [3, 14]. The largest one occurs in the 
vicinity of Dukhan (near the richest oil wells in Qatar) with few species which are highly stressed by both salinity and aridity.

In addition to these two regions (Sabkhas and Rawdahs), rocky desert and sand formations are the most common over the vast areas in Qatar, and sand dunes are estimated to cover 1500 square kilometers representing $12.92 \%$ of the total area of Qatar [4]. This article presents these locations along with the roles of the native plants, biological soil crusts and extremophiles in this ecosystem.

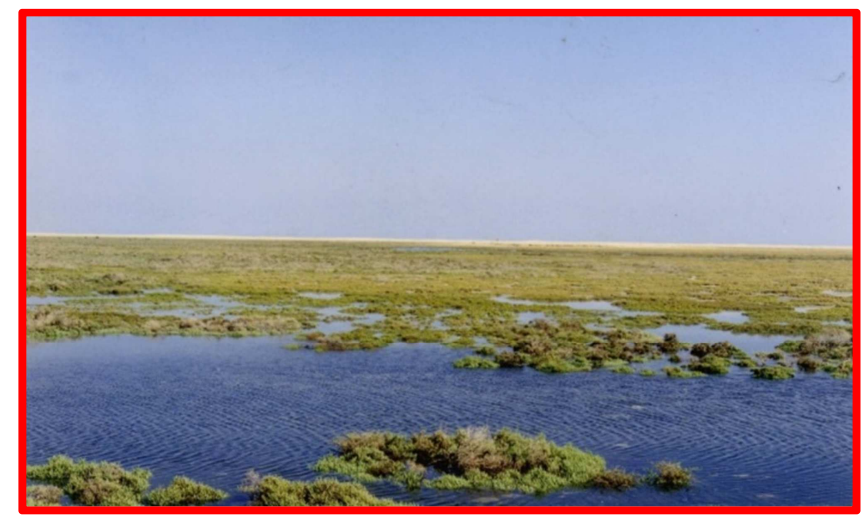

Figure 3. A Sabkha as seen from one of the study locations at-high tide.

\section{Wild Plants Versus Microorganisms: Adaptation to Arid Environments}

The main features of most wild plants in this region can be grouped under three main aspects: (1) water, (2) solutes, and (3) structures. The main mechanisms of wild plants for resisting severe environmental conditions (e.g. salinity, drought and high temperatures) at the Arabian Gulf region have recently been discussed $[1,10]$. There are three main mechanisms which enable plants to cope with those factors:

(a) Avoidance mechanisms: Plants avoid salt stress by many secondary mechanisms, for example, the extrusion mechanism is an efficient method of removing the extra toxic ions from the active sites of plant tissues to the outside surface of the plant body. Many halophytes from Qatari habitats such as Limonium axillare, Avicennia marina, Aeluropus lagopoides, Tamarix spp. and Atriplex spp. have been reported to have salt glands (Figure 4) and salt bladders. There are two types of salt glands and they differ in the number of constitutive cells: (1) salt glands of 2 cells, and (2) salt glands of 4-10 cells. The first type is found in some native plants like A. lagopoides [15], and Atriplex spp., and possibly other native plants including monocot plants, while the second type of salt glands is found in Tamarix, Limonium, and Frankenia. Several authors have described and discussed the structure and function of these salt glands $[1,7]$.

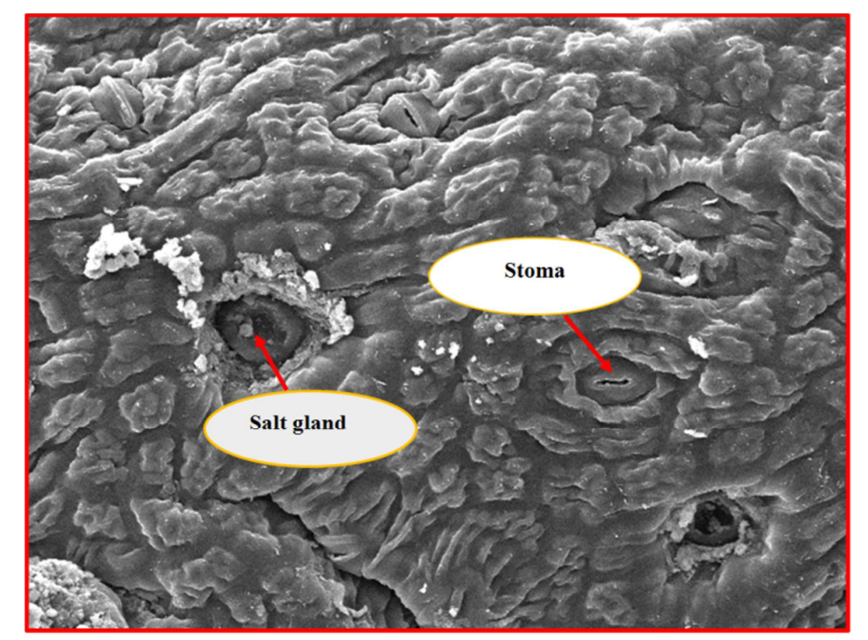

Figure 4. SEM image of the adaxial leaf surface (the upper side) of L. axillare showing salt glands with some salt crystals and stomata. Magnification $\times 400$.

Some of these halophytes have salt glands capable of excreting a substantial amount of $\mathrm{Na}^{+}$outside the plant body as compared to $\mathrm{K}^{+}$, with the best-known $\mathrm{Cl}^{-}$-ATPase pump to channel $\mathrm{Cl}^{-}$outside the plant body. This situation protects plants from toxic ions in the growth medium [16]. An ion exclusion mechanism is found in Date Palm (Phoenix dactylefera) trees and mangroves (Avicennia marina) by keeping low levels of toxic ions like $\mathrm{Na}^{+}$and $\mathrm{Cl}^{-}$ at the top of plants, while most of these ions were retained in the root system or might be excluded to the soil environment [17, 18].

Other mechanisms are also operating in glycophytes and some halophytes that do not have salt glands or salt bladders. Ions are compartmentalized in non-active cell organelles with little metabolic activities such as cell walls and vacuoles. Halophytes like Suaeda maritima could have such a mechanism to avoid toxic ions as the activity of enzymes in the active cell organelles like chloroplasts are inhibited by salts in a similar manner to that in glycophytes. Despite the apparent compartmentalization process found in this plant, this mechanism might be considered as a tolerant mechanism, since plant tissues still contain substantial amounts of salts with the appropriate management of extra ions. When the barriers at the root system failed to exclude toxic ions like $\mathrm{Na}^{+}$and $\mathrm{Cl}^{-}$, some other plants of the flora of Qatar like Ricinus communis adopted other mechanisms, these ions might be re-translocated back from the top of the plant to the root tissues or even to the root environment. Much studies are still required about other halophytes in the Qatari habitats and other parts of the Arabian Gulf region. The third avoidance mechanism in these plants include salt dilution as found in halophytes like Salsola soda (Figure 5). Extra accumulated salts in the tissues of these plants can be diluted to keep the cytoplasmic salinity below the toxic levels, and these plants are considered as salt includers.

In native plants, drought avoidance mechanisms can be seen through conservation of water in their leaves; Tetraena qatarense is a good example [1], or by 
acceleration of water absorption, as observed in Helianthemum lipii (Figure 6). More details can be found in some recent articles $[1,10]$ with good examples from the flora of Qatar.

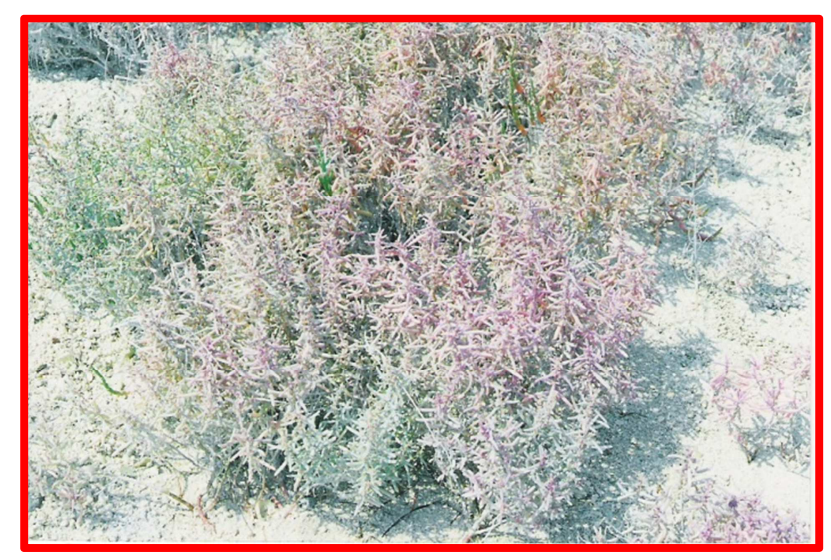

Figure 5. Salsola soda. Salt includer.

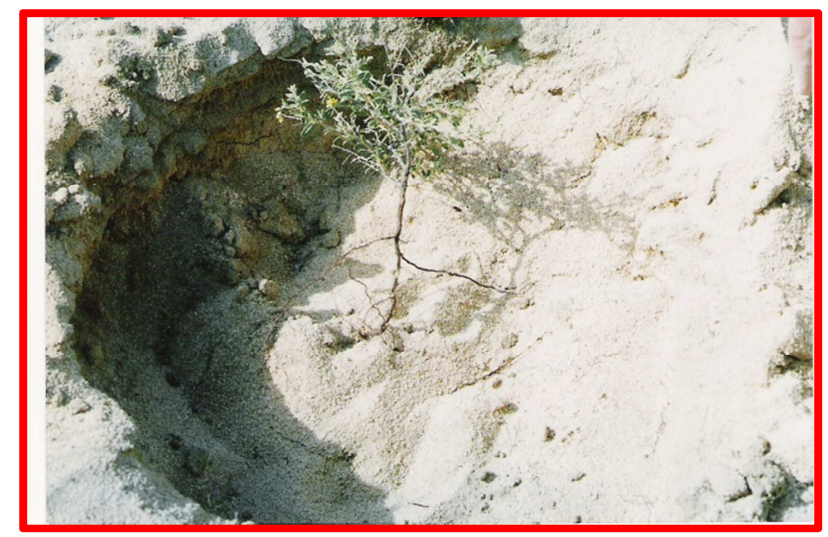

Figure 6. Helianthemum lipii. This plant extends deep roots into the soil to facilitate water absorption.

(b) Tolerance mechanism: Plants tolerate severe environmental conditions mainly by the accumulation of organic and inorganic solutes. Compatible osmolytes such as proline, gylycinebetaine, soluble sugars such as trehalose and some organic acids are accumulated in plant tissues to cope with the harsh environments of salinity, drought and high temperatures $[1,12]$. Ascorbic acid (vitamin C) as an organic acid, accumulates under extreme saline conditions, and it is worth discussing its role here; as an enzyme cofactor might play many functions especially those related to photosynthesis and growth [19]. In fact, saline habitats encourage the production of reactive oxygen species (ROS) in plants [20,21], and the last step of the pathway (Figure 7) is to show how native plants produce this organic acid as an antioxidant agent to ease the oxidative stress, thereby providing help in terms of coping with the harsh environments of osmotic stress.
UDP - D -glucuronic acid

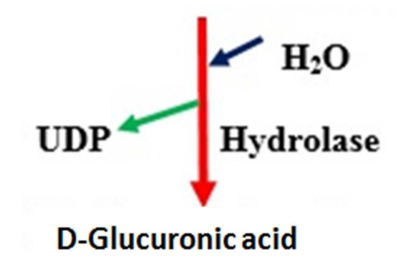

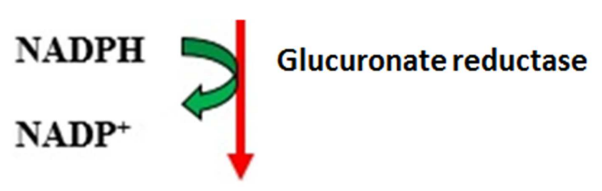

L-Glucuronic acid<smiles>CC(C)CC(C)C(C)O</smiles>

L-Gulonolactone

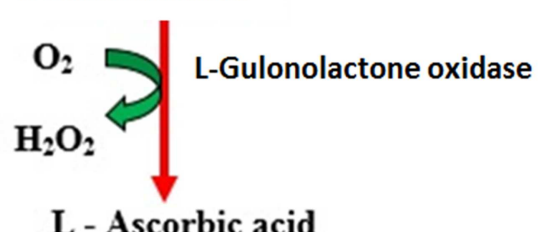

Figure 7. Ascorbic acid biosynthesis in plants under stress.

Halophytes are capable of finding cheap methods of coping with salt stress, the sequestration of inorganic ions mainly $\mathrm{Na}^{+}$and $\mathrm{Cl}^{-}$in the vacuoles might save plants a lot of energy and metabolites. Osmoregulation methods involve the internal distribution of toxic ions and organic compatible osmolytes around the cell; this is unlike the exclusion mechanism mentioned above. Conversely, xerophytes are able to accumulate various organic and inorganic solutes to achieve osmotic adjustment, osmoregulation, and experience changes in the physical properties of the cell wall. Certainly, such activities could lower the osmotic and water potentials so as maintain the water balance between plants and their environment, and to resist the internal water shortage. Tetraena qatarense and Ochradenus baccatus are good examples of xerophytes which accumulate organic solutes such as proline and soluble sugars to withstand water stress $[6,9]$. Some desert plants open their stomata even under severe soil water shortage to maintain photosynthesis with low transpiration rate $[1,17]$. In the last four decades, several articles and monographs have discussed these dehydration avoidance mechanisms [9, 10, 16, 22, 23]. Moreover, dehydration tolerance methods such as: uncoupling of photosynthesis from transpiration, low respiration rate, changes in protein synthesis and hydrolysis, etc., are additional mechanisms which allow wild plants to succeed in such harsh habitats of the Arabian Gulf region [17]. Haloxylon salicornicum, Arthrocnemum macrostachyum and Seidlitzia rosmarinus are good examples from the Qatari habitats, these plants are well adapted to arid and semi-arid environments. These plants are typically tolerant to both dry 
lands and saline soils. Figure 8 shows that these plants survive very dry sandy soils and perhaps thrive in such habitats.

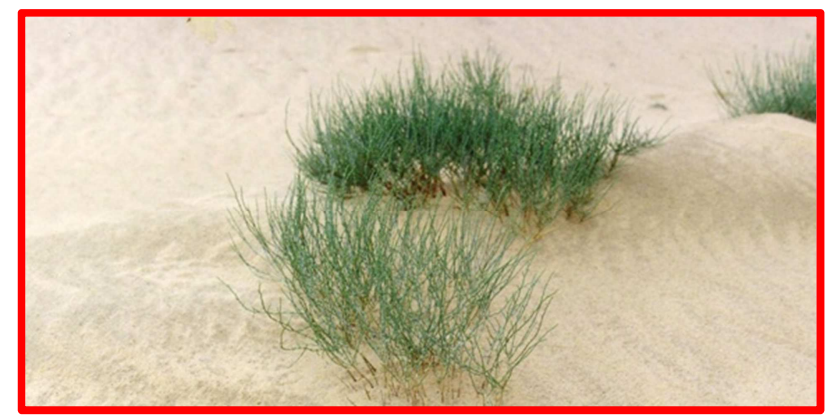

Figure 8. Haloxylon salicornicum thrives on dry sandy soil. This plant is tolerant to drought and salinity.

(c) Escaping mechanism: Living organisms escape harsh environmental conditions by different methods, activities and behaviours. For example, quickly completing their life cycle when the environmental conditions are in favour of growth, and then imposing a quiescent period (dormant stage) to pass the harsh episode of environmental stresses, or, committing death partially or totally when those environmental conditions worsen. Some desert herbs (ephemerals) complete their life cycle in a very short period of time when water is available after heavy rains. Their dormant seeds, germinate, grow, flower and reproduce before the dry season, and produce more dormant seeds for the next rainy season. Two examples (Senecio desfontainei and Polycarpaea spicata) can be found in the flora of Qatar (Figure 9, and [1]. Thus, under the arid conditions of the Arabian Gulf region, there is early maturation of herb plants and when the produced seeds are left dormant for a period of time before the next rainy season, this could be a good strategy for escaping severe environmental conditions. The traits in these plants might be experimental materials for modern molecular biology and biotechnology for the development of crop plants that can complete their life cycle within a short period of time, in order to escape periods of severe water shortage [24].

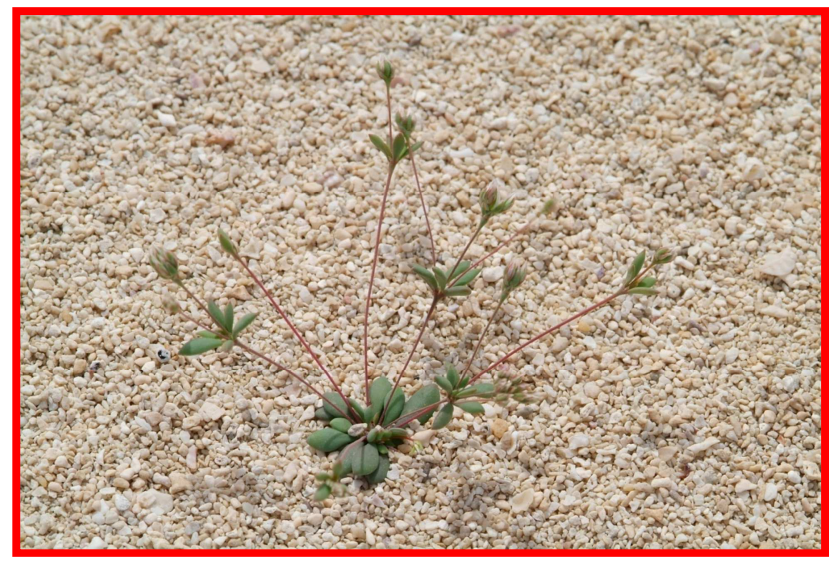

Figure 9. Polycarpaea spicata. Drought-escaping herbs. (Courtesy of Abdel-Bari, E. M. M, 26 May 2011).
The death of leaves or whole plants has been considered as a strategy of escaping adverse environmental conditions. One interesting example is the Halocnemum strobilaceum community at some Sabkhas in Qatar; plants die at the center (Figure 10, A, B) showing bare patches of dead branches and green growth at the periphery. These gradually spread towards the edges of the mat (Figure 10, C). Another example is Halopeplis perfoliate which accelerates leaf death to reduce the number of active green leaves, so as to maintain the plant's life (Figure 11). In some sabkhas, at very high salt stress the land could be left as barren. This kind of death is considered as the last desperate method by some native plant species to escape the severe osmotic stress of salinity and drought. As discussed above, many reports have concluded that while roots serve as the real barrier against the excessive uptake of salts, plants have many other options to redistribute toxic ions around the plant body like excluding these ions to less functioning organs (leaf sheaths and petioles), or retranslocating toxic ions to roots and finally to the root environment. For example, the sodium ion $\left(\mathrm{Na}^{+}\right)$may be transported from leaves to roots and then to the rhizosphere [25].
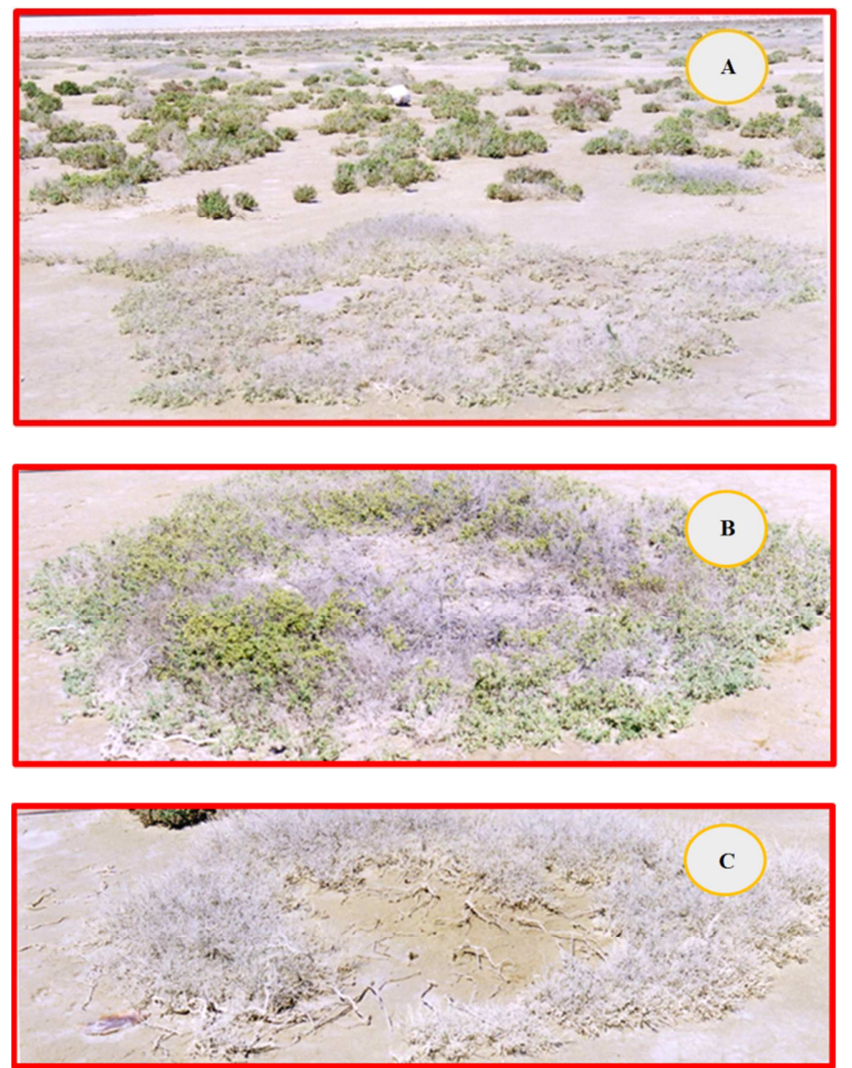

Figure 10. The death of leaves and plants of Halocnemum strobilaceum could be a strategy for escaping stress conditions.

Many halophytic plants can extrude or include extra salts by their salt glands or dilution mechanisms respectively. Also, some plants have the ability to exclude toxic ions to less active organelles like the apoplastic systems (cell walls) or vacuoles. Such a situation keeps the active machinery of the cell (cytoplasm) safe and away from the harmful ions, and when 
salts accumulate inside the cells, cells might be killed unless the salts are compartmentalized in vacuoles and other nonactive organelles [26]. Such strategies could minimize or delay the toxic effects of ions like $\mathrm{Cl}^{-}$and $\mathrm{Na}^{+}$. However, if plants fail to achieve all these processes, the plant's last option to ensure survival is the partial death of some parts (changing colour of leaves and / or death of leaves) (Figure 12), otherwise the whole plant will die as a result of failure to cope with the harsh environmental conditions [27].

Leaf senescence and death are important events in determining the total leaf area of plants, thereby affecting their productivity. Plants normally tend to keep the number of living leaves relatively constant [28], and environmental conditions may have a great impact on the rate and timing of leaf death. Salt stress, for example, might cause the accumulation of toxic ions like $\mathrm{Na}^{+}$and $\mathrm{Cl}^{-}$in leaves which induce shedding them [29-31]. Earlier studies on Mexican wheats [32] showed that leaves die as the concentration of $\mathrm{NaCl}$ increased in the growth medium, and chloride was found in large amounts in the dead leaves under salt stress.

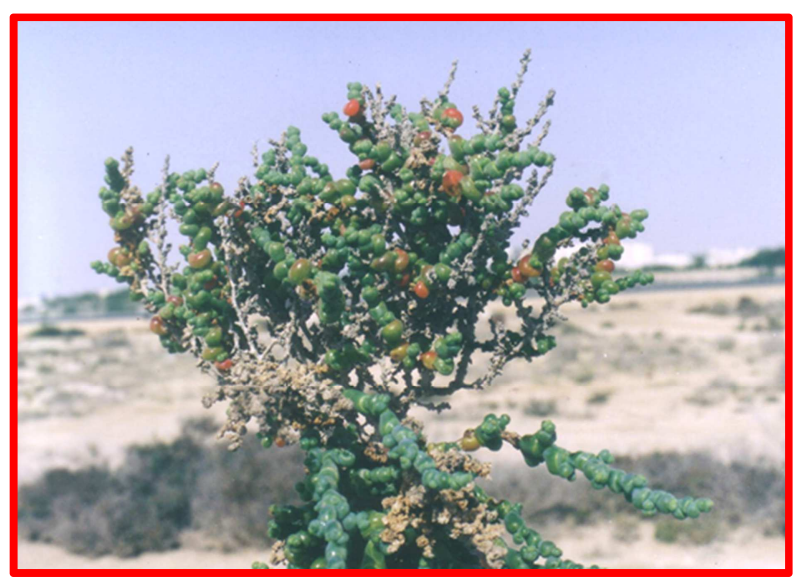

Figure 11. The death of Halopeplis perfoliate leaves could be a strategy for reducing the number of active leaves, so as to save the life of the whole plant.

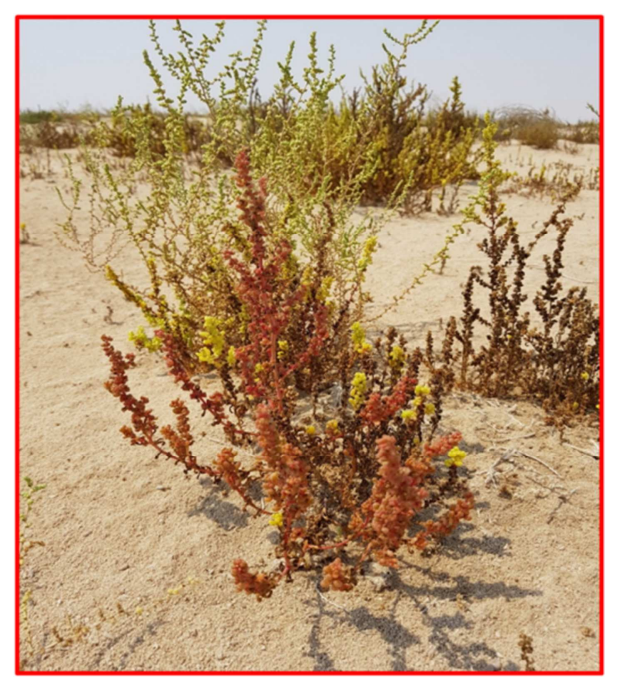

Figure 12. Desert plants getting different colours due to the severe environmental conditions, dying partially or totally, while some others are staying green and thrive under such dry lands.
In fact, the timing and the rate of leaf death could be regarded as a reliable criterion in the varietal differences between crops, as their ability differ in the accumulation of chloride in the mature leaves, a process which could lead to the premature senescence of mature leaves and perhaps, result to the death of these leaves thereby determining the number of active leaves and reduce the plant surface responsible for photosynthesis, growth and productivity [33, 34]. Previous studies on the physiology and biochemistry of these activities showed that the chlorophyll and protein contents were reduced in intact leaves of crops (such as Phaseolus vulgaris) as $\mathrm{NaCl}$ increased in the growth medium and resulted to a rapid senescence [35]. The hormone imbalance under $\mathrm{NaCl}$ stress could have an adverse role in the process of leaf senescence and death [36, 37]. Then, more investigations were carried out to confirm the impact of environmental conditions (temperature, drought, salinity, nutrient deficiency, insufficient light) on growth regulators, productive growth, and the consequent events which culminated to senescence and death. Molecular investigations have come to the conclusion that signals from these factors could cause changes in gene expression and up-regulation of many senescence-associated genes that cause various types of physiological and biochemical changes: decline in photosynthesis, degradation of macromolecules, mobilization of nutrients and ultimately cell death [38, 39]. The question that must be raised is whether leaf death is considered as a process of escaping the severe environmental conditions. The inability of plants to cope with such conditions, might get rid of leaves partially or totally by accumulating toxic ions in the mature leaves, a process which facilitates their shedding by accelerating the death of these leaves to reduce the active plant surface and maintain the potentiality of plants. Studies have confirmed that the accumulation of excess salts in older leaves may cause shedding and these leaves were replaced by new leaves with low salt content [40, 41]. In fact, this strategy of replacing older leaves by new leaves during the life span of the plant, is a strategy found in almost all perennial and annual plants [25]. Some authors [42] have confirmed that such accumulation could be regarded as a mechanism in controlling ion homeostasis and thereby salt resistance in plants such as halophytes. Moreover, some theories have suggested suspending the ageing of younger leaves as a strategy of resistance against harsh environmental conditions [32, 43, 44]. Recently, some authors [45] stated that the leaves of some plants do well in maintaining greenness and their photosynthetic function than others, in the presence of high levels of $\mathrm{Na}^{+}$in tissues under salt stress, which clearly proved the earlier theories. Further studies are required to investigate the above theories about the mechanism of senescence under stress conditions. Finally, the general conclusion is that plant death is the final stage of escape from the worst fate facing plants under severe conditions.

Mechanisms operating in microorganisms: The methods and processes adopted by microorganisms to deal with the harsh environments can be grouped under the umbrella of 
regulation of inorganic ions and the accumulation of organic solute. These organisms cope with severe environments as individual cells rather than complex multicellular organisms through two main mechanisms; 1) the salt-in strategy and 2) organic-osmolyte mechanism [46]. The salt-in-strategy means that the dominant ion in the cytoplasm is $\mathrm{K}^{+}$, an inorganic ion that has long been considered as the main compatible inorganic ion found in the cytoplasm. $\mathrm{K}^{+}$plays very important roles in maintaining water balance and ionic strength inside the cell and also serves as an enzyme activator for many metabolic processes. In fact, the regulation of all types of solutes depends on the characteristics of the plasma membranes, types of protein transporters and the enzyme systems of the cell wall and the cytoplasm. Published articles and reports on this subject showed that microorganisms differ in their regulation of inorganic solutes. For example, halophilic archaea keep the cytoplasm with very little accumulated sodium, while potassium along its counterion chloride accumulates substantially to conduct various types of functions and activities. Other halophilic anaerobic bacteria use different tactics, Haloanaerobium praevalens showed that both $\mathrm{K}^{+}$and $\mathrm{Na}^{+}$are the dominating cations at the stationary phase as well as in the exponentially growing cells. Such a situation imposes some kind of preferential accumulation of organic residues that balance the ionic strength inside the cytoplasm [47]. The second mechanism is the organic-osmolyte mechanism, and it involves the accumulation of various organic solutes mainly compatible solutes to balance the osmotic stress of the growth medium. Extremophilic microorganisms like those in the Sabkhas of Qatari habitats have adopted this mechanism to survive the harsh environment of high temperature and salinity under arid land. They accumulate organic low molecular weight compounds like ectoines and others such as a range of extremolytes with heterogenous chemical structures [48], and other compatible solutes such as quaternary ammonium compounds (glycinebetaine), amino acids (proline), carbohydrates or their derivatives, sugars and polyols. One peculiarity of organic solutes is that their accumulation can be achieved by either de novo synthesis or by uptake from the surrounding environment, and the ability to influx and / or efflux inorganic toxic ions regulate the mechanisms of resistance against harsh environmental conditions. These organic solutes offer many functions to these microorganisms, including physiological and biochemical functions, and act as protectors against heat, desiccation, freezing and salinity. The main functions of these organic solutes include: (1) maintaining osmotic equilibrium across plasma membranes, and (2) stabilizing proteins and the whole cell. Moreover, they have various biotechnological applications [49]. These include: (1) protein and/or enzyme stabilizers, (2) cosmetic uses, (3) therapeutic agents, (4) bioremediation, and (5) improving the salinity tolerance of crop plants by HGT [12].

As a general conclusion, microorganisms and plants have common cellular basics of physiological and biochemical activities in dealing with extreme environmental conditions. However, water conservation and structural modifications against drought and salinity differ in both major groups. Microorganisms are able to conserve and maintain their activities and life through the formation of spores, while plants are capable of undergoing more structural modifications and activities to avoid and tolerate harsh environments.

\section{Studies of Biological Soil Crusts (BSC)}

Since it is an arid environment, a limited number of higher plants are found in Qatar. Also, the land does not support the growth of organisms which require moist conditions for most of their life cycle. Therefore, it is not surprising that a limited number of species of fresh water algae, fungi and mosses were recorded in the State of Qatar. Moreover, the information available is very sparse in spite of the significant research activities conducted during the last two decades to study the biodiversity in the Arabian Gulf States especially in the State of Qatar, and more details can be found in websites [50, 51]. However, significant works have been conducted in some countries in the Middle East and substantial successes were achieved in the investigation of BSC [52]. In fact, BSC is comprised of various communities of bacteria, fungi, algae, lichens, cyanobacteria, and mosses, which play significant roles in improving the nutritional status of soil by carbon and nitrogen fixation and inhibiting more deterioration of the physical features of the soil, by stabilizing the surface and preventing erosion [53]. Microorganisms play significant roles in the wild life and soil biota which affect many activities and energy equilibrium of the ecosystem. Studies on the microbial communities in Qatar commenced during the eighties of the last century. Pioneer studies on soil fungi were conducted in 1980-1982 to determine the types of fungi in Qatari soils [54]. This project recorded the presence of 53 genera, 142 species and 8 varieties representing different locations in Qatar. The most common genera found in Qatari soil are: Aspergillus, Penicillium, Fusarium, Cladosporium, Stachybotrys, Acremonium, Botryotrichum, Alternaria, Microascus, and others listed by [4]. Further survey on macro-fungi including truffles in Qatar were further investigated by [55]. Among these fungi, many genera belonging to 11 families and 7 orders have been identified. Truffle genera like Terfezia and Tirmania in the family Terfeziaceae, order Pezizales were interesting, as they prefer high $\mathrm{pH}$ calcareous soils, typical of desert soils. These species form mycorrhizas on roots mainly of members of the genus Helianthemum; an example of which is $H$. lipii. The environmental and climatic reasons behind the thriving of these fungi have been discussed. Two common truffles, Terfezia claveryi (Ikhlasi) and Tirmania nivea (Zubaidi), have been giving great attention in the Qatari society.

Lichens are formed by a symbiotic relationship between a fungus and green algae or cyanobacteria, which has been 
paid a great deal of attention and given substantial efforts since such combination serves the ecosystem by offering many important functions, especially in the State of Qatar. It seemed BSC at the Arabian Gulf region developed as a result of the interaction between microorganisms like cyanobacteria and the physiochemical characteristics of soil [56], as desert crusts harbor a substantial diversity of microorganisms like fungi [57] which play critical roles in the ecosystem by improving the soil structure and fertility, water status, soil stabilization, water retention, as well as carbon and nitrogen fixation [58]. In Qatar, the contribution of microorganisms in the soil crust has been poorly studied and investigated. In fact, in 1997 four lichens species were reported for the first time as addition to the flora of Qatar [59, 60], these were Ramalina farinosa Ach (fruticose lichens), Acarospora sp., Buellia spp., and Caloplaca spp. (crustose lichens). Thereafter, other authors [61] reported twelve species of lichens; composed of ascomycetes as the main fungal part while cyanobacteria served as the autotrophic part [53]. In fact, three main groups of lichens have been recognized and reported in Qatar: (1) crustose lichens, (2) fruticose lichens, and (3) foliose lichens [4]. There are many methods of identification, however, the morphology and ultrastructure have been widely utilized around the globe [62].

Non-vascular plants including mosses are confined to a very limited number of species, and no taxonomic studies have been conducted to identify this group. Authors like [63] reported one moss genus (Funaria); collected from the soil surface of potted plants and from various moisty soils after heavy rains (Figure 13). One fern species (Ophioglossum polyphyllum) which occurs in many parts of the country, has been recorded in Qatar [60, 63].

Case study of lichens at Rawdahs-Northern Qatar: In this location, the mean annual temperature during summer time is about $42^{\circ} \mathrm{C}$ and the absolute temperature may rise up to $50^{\circ} \mathrm{C}$, while during winter period the mean annual temperature is about $23^{\circ} \mathrm{C}$, with high humidity during most months of the year. The expected rainy season extends from October to March with a well-defined dry period in July. The soil is almost shallow, sandy and rocky, and show different levels of alkalinity and salinity depending on the influence of geological substrates at each site.
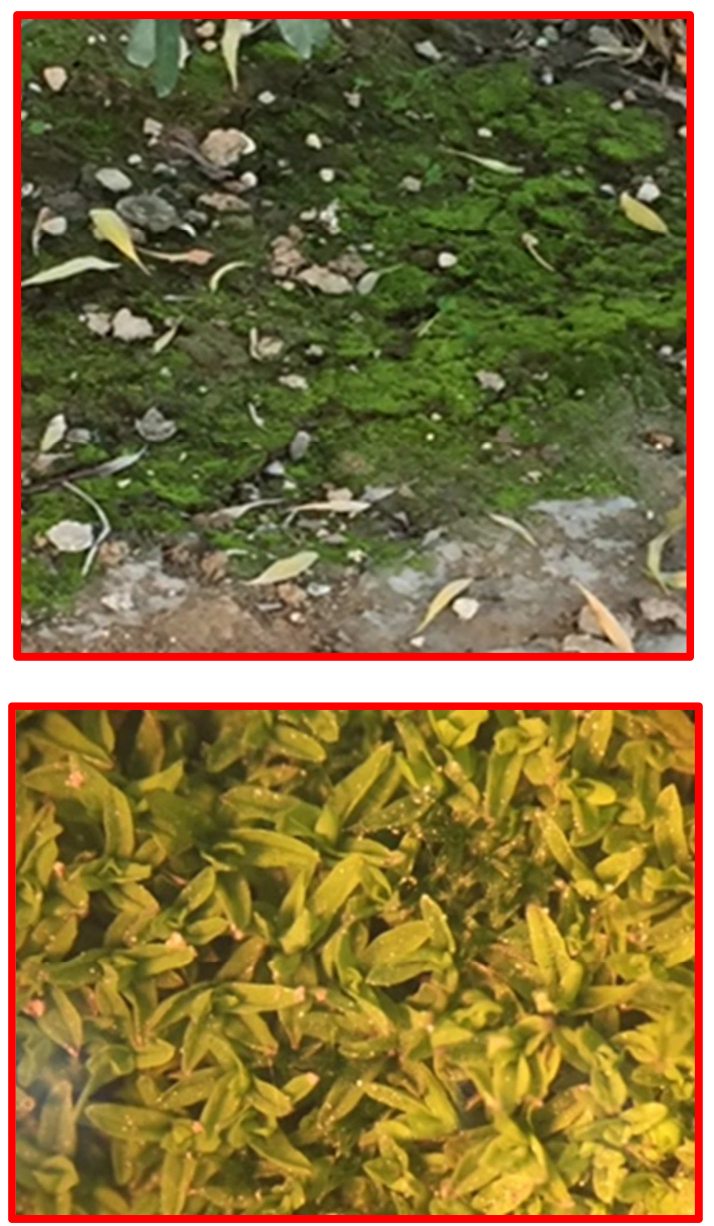

Figure 13. Little species of mosses found in Qatari habitats. This image was taken in a private garden with ample moisture in its soil.

Samples were collected from a private farm in NorthernQatar, and these samples of BSC were collected from areas of $50 \mathrm{~m}^{2}$ each during the dry season, June 2016 (Figure 14 A). To preserve their integrity, samples of BSC were taken from the central part of the area and placed in plastic boxes with care, and kept until they were transported to the laboratory for analysis. Samples were collected again after heavy rains in April 2017 (Figure 14 B) adjacent to the plants which thrived in that period. Table 1 shows some physical and chemical properties of the soil samples collected from this Rawdha as compared to those from different locations of Sabkhas, which clearly indicated the presence of much clay, high field capacity, and acceptable $\mathrm{pH}$ values (between 6 and 8), and low salinity which ranged between $6-8 \mathrm{dSm}^{-1}$.

Table 1. Some physical and chemical properties of soil samples collected from different locations of Sabkhas and inland Rawdahs.

\begin{tabular}{|c|c|c|c|c|c|c|}
\hline Location & Soil texture & Field capacity (\%) & $\begin{array}{l}\text { Soil water content } \\
(\text { of } \mathrm{FC} \%)\end{array}$ & Absolute water content (\%) & $\begin{array}{l}\text { pH (soil } \\
\text { extract) }\end{array}$ & $\operatorname{ECe}\left(\mathrm{dSm}^{-1}\right)$ \\
\hline Doha & Sandy-Sandy loam & $26^{*}$ & $7-61$ & $2-18$ & $7-10$ & $31-177$ \\
\hline Al-Khor & Sandy loam- Loamy sand & 37 & $6-10$ & $2-3$ & $8-9$ & $>200$ \\
\hline Ras-Al-Matbakh & Sandy-Silty loam & 38 & $11-51$ & $2-28$ & $6-8$ & $12-49$ \\
\hline Al-Dhakhira & Sandy loam & 30 & $43-71$ & $12-26$ & $8-9$ & $>200$ \\
\hline Inland Rawdahs & Loamy sand-Sandy clay loam & 40 & $9-12$ & $3-4$ & $6-8$ & $4-6$ \\
\hline
\end{tabular}

*All data are mean or a range of 10 readings. ECe was measured according the method described by [64]. 


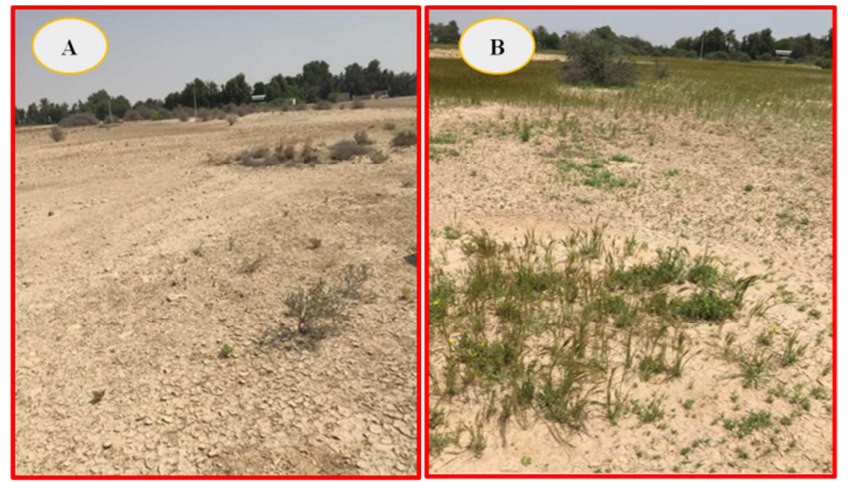

Figure 14. The sampling site before (A), and after rainy (B) seasons.

The vegetation of the area at that period consisted mainly of xerophytic shrubs and Ephemerals which is dominated by Suaeda aegyptiaca, Stipa capensis, Anastatica hierochuntica, Fagonia indica, Lycium shawii, Pulicaria gnaphalodes, Plantago ovata as well as other grasses and herbs (Figures 9 and 15).

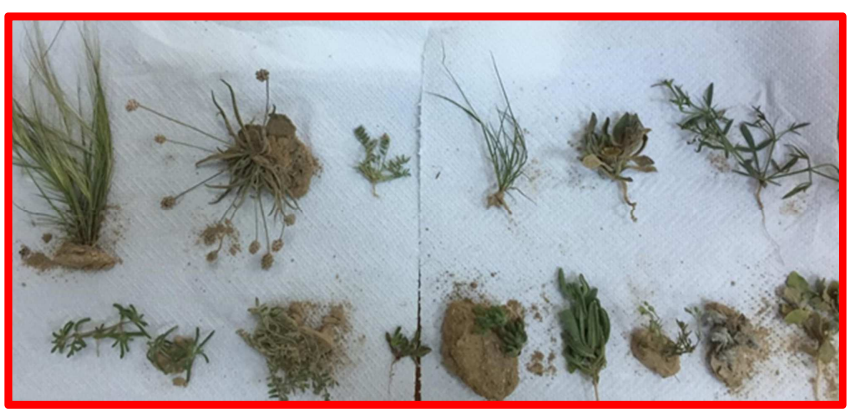

Figure 15. Ephemerals found in the study location, which are supported by BSC including lichens. These herbs germinate, grow and reproduce before the dry season.

During the dry season, soil surface of the study location shows cracks and a substantial number of lichens colonies of different types (Figure 16). These colonies play a significant role in the biological activities of the soil and contributed actively to the thriving the biodiversity [57, 58]. Such colonies might be found on rocks of different types and shapes which serve as growth substrate and provide minerals to them, lichens on rocks play a significant role in rock weathering and breakdown in arid and semi-arid environments [4], and to support the growth of many desert plants. Soils of the study site contain some thermo-halophilic bacteria which belong to the genus Bacillus and other microorganisms like the cyanobacteria Microcoleus, with significant presence of many species of Nostoc and Anabaena, and possibly other genera that play crucial roles to support the soil with various types of biological activities [11]. Green algae are found on the rocks, and, in particular some unicellular green algae are found especially after heavy rains.

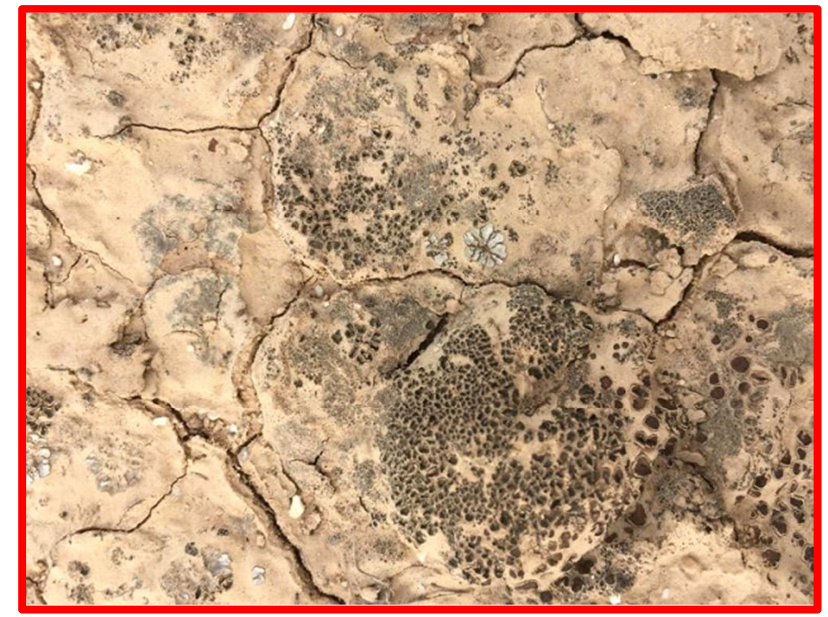

Figure 16. Various types of lichens colonies found on different patches of the study site appeared on the soil crust.

The many possible important roles played by BSC in the desert environments include: (a) increasing the nutrient content of soils: nitrogen fixation is one example especially in Qatar, as the soil suffers from low nitrogen availability [7, 65], (b) stabilizing soil surfaces and preventing soil erosion by their contribution to soil formation and structure. For example, lichens can help in providing organic matter, water retention and in the collection of soil components like dust and silt which enrich the soil with some nutrients [4, 53], (c) monitor atmospheric pollution $[66,67]$ as a result of expansion in the industrial activities of the oil and gas sectors in Qatar [61], (d) some other benefits and advantages can be obtained for any future plans to use lichens in the human life; these include food preparation and diets, textile industry, chemistry, medicine, pharmacology as well as cleaning the environment from various types of pollution ... etc [68-72].

Studies on bacterial communities in Qatar:

Studies on bacterial communities did not commence until the beginning of the current century, our records showed that these studies did not exceed reporting the presence of some genera and species at various habitats. For example, studies like $[73,74]$ have shown that the decomposition rates in the shoot system (leaves) of Avicennia marina L. were highest in the summer season, and the bacterial groups that predominated during these processes were those that do not form spores (non-spore forming bacteria) and were in the order: Amylolytic $>$ proteolytic $>$ cellulolytic, and the least ones were the spore forming bacteria. The follow up investigation of the heterotrophic aerobic marine bacteria of the above groups revealed the bacterial counts during the period April 1998 to February 1999 which showed some differences depending on the atmospheric temperatures, such conditions might have had a significant role in releasing substances from the leaves of that plant, thereby affecting the bacterial counts. These studies did not go further to identify these groups, genera and species. This is the first time that the ecology and biodiversity of Streptomyces is being studied in the soil of Qatar, in many sites around the country. The 
morphology of the isolates of this genus have a common form of colony, they are spherical, smooth, elevated with diameter mainly ranging between 1-5 $\mathrm{mm}$ [75]. The bacterial inhabitants in the soil (Figure 17) adjacent to many halophytes and in the rhizosphere of these plants at the coastal zone and at the inland zones were investigated [76]. The results of this study showed that the total bacterial counts were higher in the rhizosphere of plants at the coastal line as compared to those of the non-rhizosphere soil and at the inland areas as well. Gram positive cocci predominated in isolates from the rhizosphere and non-rhizosphere soil, while Gram-positive bacilli were predominant in aqueous washings of phyllospheres of the green and senescing parts of these plants. One important result that should be reported here is the presence of low bacterial colonization on the phyllosphere of the halophytes which have a salt extrusion mechanism than those which adopt dilution mechanism to avoid salinity.

Escherichia coli was investigated in some ponds around Doha city [77]. The study revealed that this bacterium is prominently present in untreated ponds (Abu-Hamour pond) compared to treated ones (Abu-Nakhla pond). Other bacteria species were also found, and these included: Aeromonas hydrophilia, Pseudomonas aeruginosa, Klebsiella pneumoniae and Chromobacterium violaceum.

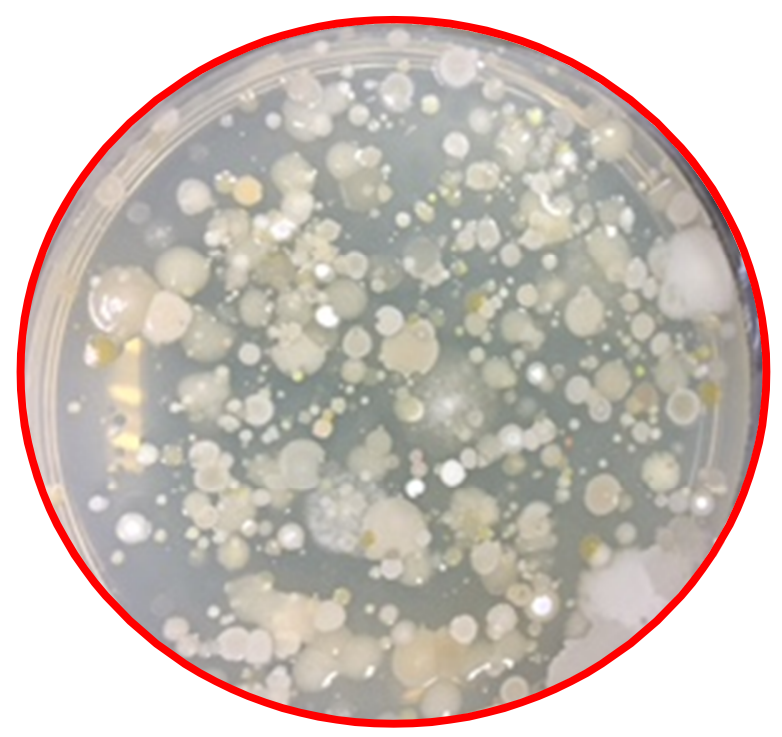

Figure 17. Diversity of bacterial species isolated from Sabkhas in Qatar.

The other bacterial species which were also found in the wet soil around these ponds included: Streptomyces sp., Bacillus sp. and Macrococcus sp. The isolation of some native bacterial strains like Bacillus sp., Pseudomonas geniculata and Achromobacter xylosoxidans from different locations around Qatar has also been confirmed. The above mentioned strains have the ability to degrade contaminants such as phenol derivatives and polycyclic aromatic hydrocarbons [78, 79]. Several bacterial strains have been identified during the phytoremediation processes of soil contaminated with petroleum hydrocarbons $[80,81]$ and to improve the quality of industrial waste water produced during oil and gas operations. These efforts were introduced as one of the objectives to save the ecosystems in Qatar from the real risks and consequences of the expansion in the industrial activities [1]. Bacterial communities have been studied through modern methods including direct counts, and also by some advanced techniques to gain more understanding of microbial abundance, diversity, and potential metabolic capabilities in various locations in Qatar [82]. Extremophiles like some bacilli species (Bacillus thuringenses and Bacillus cereus) isolated from Qatari soils (Figure 18) adjacent to native plants or associated with them (Figure 19) might play significant roles in supporting or promoting the growth of these plants.
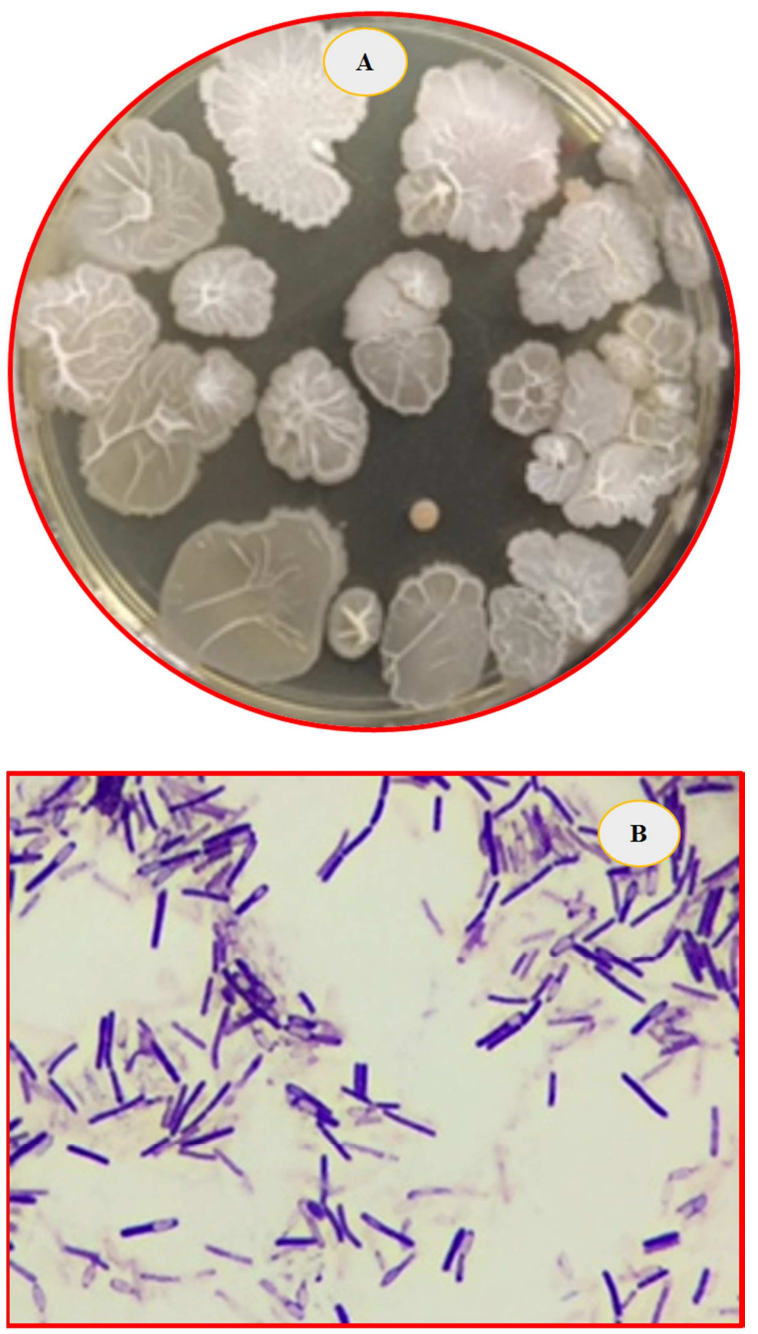

Figure 18. Bacteria of Sabkhas: colonies represent Bacillus sp.; the most common bacteria isolated from Sabkhas in Qatar (A), spore forming Bacillus bacteria as seen under the light microscope (B). (magnification: x1000).

Recently, a new approach has emerged which supports the growth and development of plants under severe environmental conditions by microorganisms which inhabitant the soil. One of the main issues that should be addressed is the possible roles of the presence of extremophiles in salt glands and on the plant body in providing some important resistance traits to the native plants as well as other biological needs [12, 83]. Microorganisms 
could be a solution to increase the plant's resistance to various harsh abiotic stresses [84], and the following are the methods and mechanisms adopted by microbes which have recently been discussed [11, 12]: (a) biofilm formation, (b) polymers production, (c) chemotaxis, (d) phytohormone production, (e) nitrogen fixation, (f) phosphate solubilization, (g) production phytohormone-degrading enzymes and (h) osmolytes biosynthesis. All these methods could provide some kind of protection for plants against various types of environmental stresses (Figure 20).

In fact, halotolerant and halo-thermophilic bacteria found in Qatari soils could offer many applications in biotechnology. These include: the production of compatible solutes [12], salt antagonists, or stress-protective agents, and other useful molecules like bio-surfactants, exopolysaccharides and enzymes which have important applications in food biotechnology, bioremediation ... etc [85]. Moreover, the advances in the modern biological techniques could offer great opportunity to study the ecology and function of microbial communities in hot desert ecosystems [86]. In fact, many studies have demonstrated that microbes might provide support for non-host plants through the adoption of a resistance mechanism that improves their ability to conduct various functions and activities in their natural habitats [87, 88].

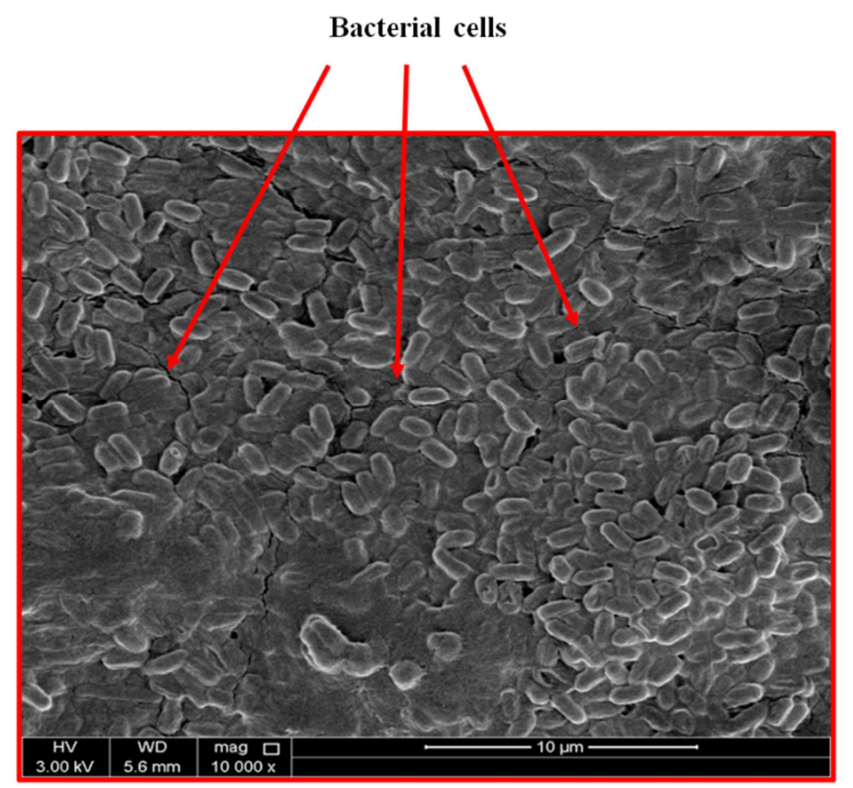

Figure 19. The SEM image shows a huge number of bacterial cells cover the leaf surface of native plants in Qatari desert.

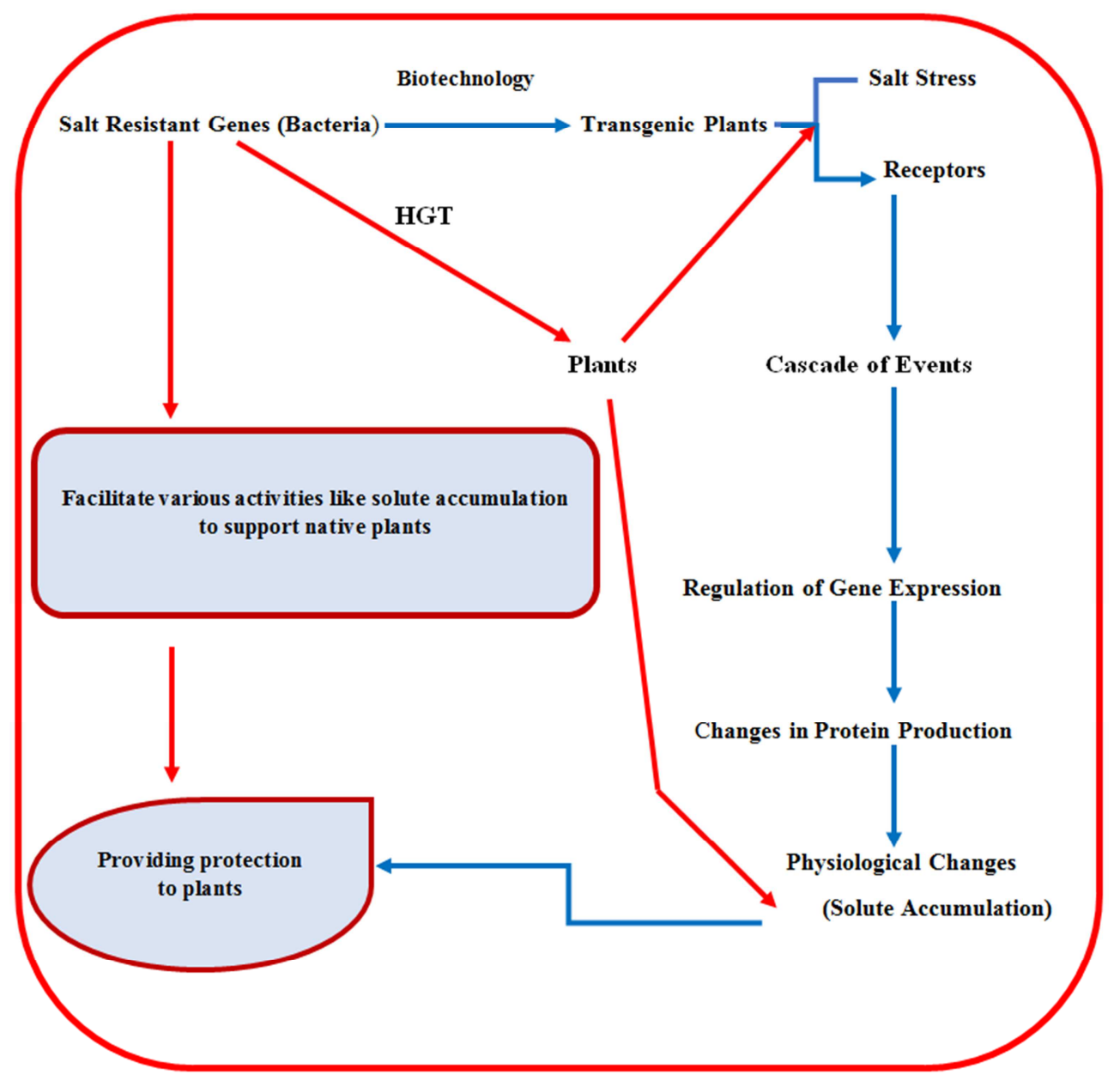

HTG: Horizontal Gene Transfer

Figure 20. The different methods and mechanisms by which microorganisms protect plants against abiotic stresses. This figure was modified from Figure (1) of [12]. 
In the meantime, more promising achievements have been made during the last twenty years around the world. This is because a great deal of attention has been placed on the production of antibiotics, since natural soils are rich with a large number of microbes capable of producing various types of antibiotics. Significant studies, especially in the third world (developing countries), have shown that a large number of bacterial isolates and fungi have antimicrobial activity. Based on several experimental works, researchers [89] have collected dozens of soil bacteria genera, including eubacteria and actinomycetes, which have different and powerful abilities to produce antibiotics. In India [90], screening was performed for potent antimicrobial compounds and at least one strain with antagonistic abilities against many test microorganisms was isolated. A study in Nigeria [91] is of interest, because genetic techniques were used to show that microorganisms can synthesize useful organic compounds such as antibiotics during their activity with soil contaminants, although only a limited number of the investigated Bacilli species exhibited antibacterial activity. More achievements have been reported from Ethiopia, as one successful breakthrough isolated actinomycetes that produce antibiotics active in fighting against antibiotic-resistant pathogens [92].

Again, the issue of the origin of activities in both native plants and their associated microorganisms is still outstanding, and the mystery of life has been strongly addressed by scientists and research centers. Also, the relationships between living organisms and their activities are still the core of their thought and interest. For example, [93] concluded that the HGT (Horizontal Gene Transfer) of antibiotic resistance traits played a crucial role in the evolution of bacteria and their diversity. In fact, since the review of [94] in evaluating the possibility of HGT from plants to microorganisms, only a few cases of HGT from eukaryotes to bacteria have been reported. There is still a possibility of introducing genes into the environment and subsequently transferring them to other organisms. More reports are available about the possibilities of HGT between living organisms and it is worth mentioning here. In their review, [95] discussed the role of HGT in eukaryotic evolution, as this approach has been more successful than traditional genetic modification methods. In fact, this approach has expanded rapidly in the last decade since many eukaryotic genes have been found to have microbial origins [96]. In a review on the early evolution of photosynthesis, [97] stated that the evidence clearly showed that photosynthesis in eukaryotic organisms originated from the endosymbiosis of cyanobacteria-like organisms, which were later converted to chloroplasts. This conclusion means that the origin of photosynthesis began in prokaryotic organisms. HGT appears to have played a crucial role in the evolution of life on Earth, and is supported by numerous events which have been observed in the genomes of the three domains of life [98]. However, although the traditional thought is that most genes in eukaryotes were derived from mitochondria and plastids, these organelles cannot explain the presence of bacterial genes in eukaryotes. Historically, HGT from Agrobacterium to plants has been considered the first event in the transfer of genes between living organisms, as this event has been considered a novel research finding of the transfer and integration of genetic materials from bacteria into eukaryotic organisms [99]. This event opened the door to expand our knowledge of modern genetic manipulations to improve the resistance of crops to environmental stresses [100].

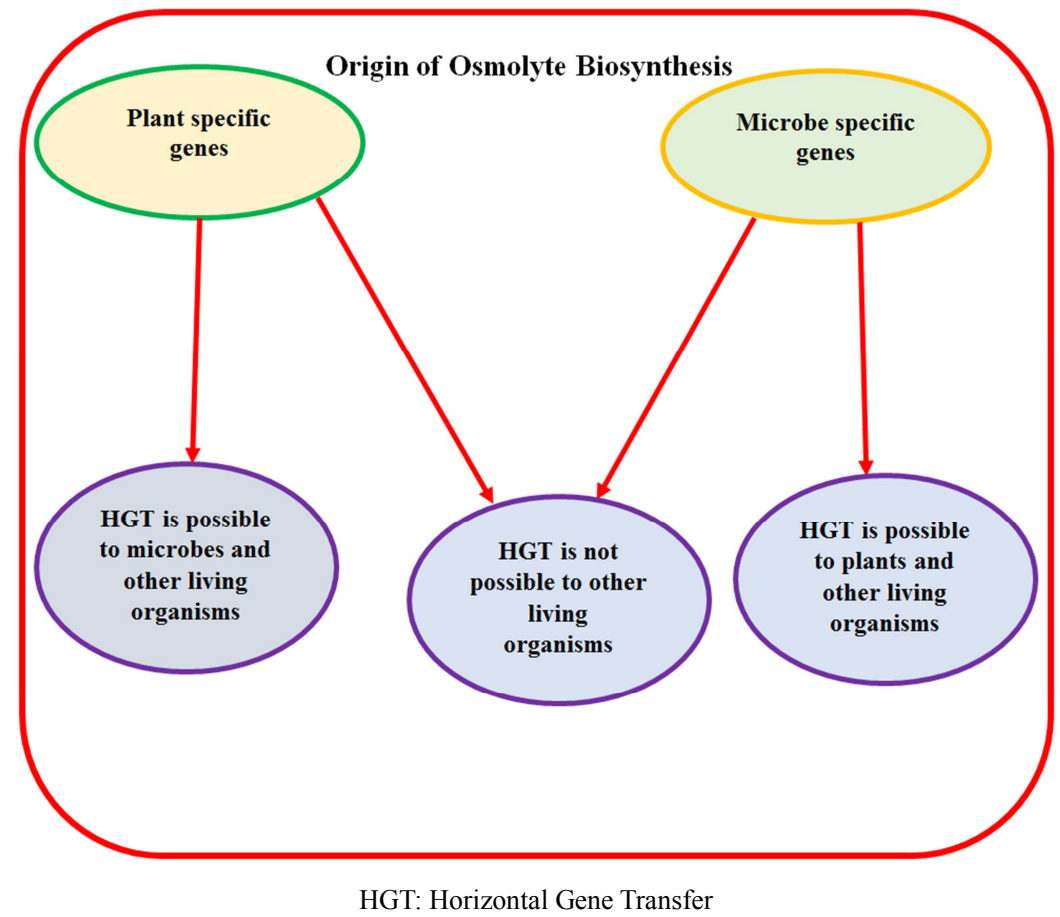

Figure 21. The possible hypotheses of horizontal gene transfer (HGT) between living organisms. 
In recent review [12], some objectives were outlined for any future plans: (1) ecophysiology of native plants, the associated microorganisms and the type of relationships, (2) study the salt glands and the plants surface with their associated microbes, (3) study the compatible solutes in plants and microbes, and (4) molecular studies to elucidate the origin of activities in plants and microorganisms. Three possibilities have been suggested about the origin of metabolic activities (Figure 21), these are: (a) plant specific genes, with possibilities of HGT to other living organisms, (b) microbe specific genes, with possibilities of HGT to other living organisms, and (c) independent origin that are found in either plants or microorganisms with no possibilities of HGT to other living organisms. Certain examples have been reported in some websites $[101,102]$. More discussions and explanations can be found in several other reports and articles [12, 103-105].

\section{Conclusion}

The different physiological and biochemical characteristics of the huge number of living organisms (BSC, plants or others), and the mechanisms they adopt in coping with harsh environments can be considered as experimental materials for more advanced and deep research. In fact, the tremendous evolution in molecular biology and biotechnology could be utilized to solve many of the problems facing humanity in the agricultural and health sectors as well as the understanding of many secrets and mysteries about the creation of life. The gene bank of these living organisms, especially those living under extreme environmental conditions, requires substantial efforts for modern manipulation to develop living organisms capable of improving, increasing and sustaining production in the agricultural and pharmaceutical sectors. Also, looking at the system: Soil-BSC-Plants, all living organisms seem to be living in an organized harmony of cooperation and support of each other. Each group, or even individual organism, has its roles to support the life and activities of mankind. In recent years, many facts have been revealed about the reality of these roles in human life as well as the methods and approaches adopted by these living organisms to bring about a sustainable support of each other. The evidence presented so far support the idea of the unity of life, and the reasons and objectives behind their creation, and such task still requires more studies for proper understanding.

\section{Acknowledgements}

The authors would like to thank the Department of Biological and Environmental Sciences, College of Arts and Sciences, as well as the Environmental Studies Centre, Qatar University, for the financial and technical support provided during the case studies.

\section{References}

[1] B. T. Yasseen, and R. F. Al-Thani, "Ecophysiology of wild plants and conservation perspectives in the state of Qatar," In: M. Stoytcheva, and R. Zlatev (Eds.), Agricultural chemistry, Chapter 3, ISBN: 978-953-51-1026-2, InTech. 2013; 37-70. DOI: $10.5772 / 55305,2013$.

[2] State of Qatar / Ministry of Industry and Agriculture / UNDP / FAO, "Reconnaissance soil classification map," 1976.

[3] K. H. Batanouny, "Ecology and flora of Qatar," The Alden Press Ltd., Oxford, U. K, The Scientific and Applied Research Centre, University of Qatar, 1981.

[4] H. A. Abulfatih, E. M. M. Abdel-Bari, A. Alsubaey, and Y. M. Ibrahim, "Vegetation of Qatar," Scientific and Applied Research Center (SARC), University of Qatar, Doha, Qatar, 2001.

[5] E. M. M. Abdel-Bari, B. T. Yasseen, and R. F. Al-Thani," Halophytes in the state of Qatar," Environmental Studies Centre, Qatar University, Doha, Qatar, ISBN. 99921-52-98-2, 2007.

[6] B. T. Yasseen, and R. F. Al-Thani, "Halophytes and associated properties of natural soils in the Doha area, Qatar," AEHMS, vol. 10 (3), pp. 320-326, 2007.

[7] B. T. Yasseen, and M. A. Abu-Al-Basal, "Ecophysiology of Limonium axillare and Avicennia marina from the coastline of Arabian Gulf-Qatar," Journal of Coastal Conservation: Planning and Management, vol. 12 (1), pp. 35-42, 2008.

[8] B. T. Yasseen, and M. A. Abu-Al-Basal, "Ecophysiology of chenopodiaceae at the coastline of Arabian Gulf-Qatar: possible destruction and prespective conservation," European Journal of Scientific Research, vol. 39 (1), pp. 90-104, 2010.

[9] B. T. Yasseen, "Urban development threatening wild plants in Doha City-Qatar: Ecophysiology is a Prerequisite for Ecological Restoration," Journal of Plant Sciences, vol. 6 (3), pp. 113-123, 2011.

[10] B. T. Yasseen, "Traits of wild plants in Qatar peninsula and research perspectives," J. Biology \& Nature, vol. 5 (2), pp. 52-66, 2016.

[11] R. F. Al-Thani, and B. T. Yasseen, "Halo-thermophilic bacteria and heterocyst cyanobacteria found adjacent to halophytes at Sabkhas, Qatar: Preliminary study and possible roles," African J. Microbiology Research, vol. 11 (34), pp. 1346-1354, 2017

[12] R. F. Al-Thani, and B. T. Yasseen, "Solutes in native plants in the Arabian Gulf region and the role of microorganisms: future research," J. Plant Ecology, rtx066, https://doi.org/10.1093/jpe/rtx066, 2017.

[13] M. M. Ashour, "Sabkhas in Qatar peninsula, landscape and geodiversity,"1/2013, pp. 10-35, ISSN 2286-0177 ICCS, Spiru Haret University, Bucharest, Romania, 2013.

[14] I. A. Mahasneh, R. F. Al-Thani, and G. Brown," The microorganisms of Sabkhat in Qatar," In: M. Ajmal Khan, B. Boer, G. S. Kust, and H-J. Barth, Sabkha Ecosystems, vol. 2, West and Central Asia, Tasks for Vegetation Science 42, H. Leith, University of Osnabruck, Germany. Springer, The Netherlands, 2006. 
[15] F. M. Salama, S. M. El-Naggar, and T. Ramadan, "Salt glands of some halophytes in Egypt," Phyton-Annales Rei Botanicae, vol. 39 (1), pp. 91-105, 1999.

[16] D. M. Orcutt, and E. T. Nilsen, "Physiology of plants under stress, soil and biotic factors, John Wiley \& Sons, Inc NY, 2000.

[17] J. Levitt, "Responses of plants to environmental stresses, water, radiation, salt, and other stresses," vol. II, Academic Press, New York, London, 1980.

[18] H. J. Aljuburi, and H. H. Al-Masry, "Effects of salinity and indole acetic acid on growth and mineral content of date palm seedlings," Fruits, vol. 55, pp. 315-323, 2000.

[19] K. Nahar, S. M. Ullah, and N. Islam," Osmotic adjustment and quality response of five tomato cultivars (Lycopersicon esculentum Mill) following water deficit stress under subtropical climate," Asian Journal of Plant Sciences, vol. 10, pp. 153-157, 2011.

[20] P. Sharma, A. B. Jha, R. S. Dubey, and M. Pessarakli, "Reactive oxygen species, oxidative damage, and antioxidative defence mechanism in plants under stressful conditions," Journal of Botany, vol. 2012, Article ID 217037, 26 pages, http://dx.doi.org/10.1155/2012/217037, 2012.

[21] R. Ksouri, A. Smaoui, H. Isoda, and C. Abdelly, "Utilization of halophytes species as new source of bioactive substances," Journal of Arid Land Studies, vol. 22 (1), pp. 41-44, 2012.

[22] L. G. Paleg, and D. Aspinall, "The physiology and biochemistry of drought resistance in plants," Academic Press, Sydney, New York, London, pp. 492, 1981.

[23] W. Larcher, "Physiological plant ecology, Ecophysiology and stress physiology of functional groups," 4th ed., Springer, Berlin, 2003.

[24] M. K. Omara, "Selection of early maturing barley with improved response to drought stress," Aust. J. Agric. Res, vol. 38, pp. 835-845, 1987.

[25] P. Adam, "Saltmarsh ecology, "Cambridge University Press, 1993.

[26] R. Munns, "The impact of salinity stress: (1) The environmental and physiological nature of salinity," CSIRO Division of Plant Industry Canberra ACT, Australia. http://plant stress.com/articles/salinity_i/salinity_i.htm, 2017, Accessed on $29^{\text {th }}$ October 2017).

[27] R. Munns, "Comparative physiology of salt and water stress," Plant Cell \& Environ, vol. 28, pp. 239-250, 2002.

[28] R. H. M. Langer, "How grasses grow," $2^{\text {nd }}$ edition, Studies in biology No. 34, Edward Arnold Ltd, 1979.

[29] H. O. Kostina, "Gradient distribution of chloride and ash in plants and its ecological significance," Ukr. Bot. Zh, vol. 31, pp. 322-326, 1974.

[30] E. V. Maas, and R. H. Niemen, "Physiology of plant tolerance to salinity," In: Crop tolerance to suboptimal land conditions, ASA, Special publication number 32, American Society of Agronomy, Medison, USA, 1978.

[31] R. Munns, and M. Tester, "Mechanisms of salinity tolerance," Annu. Rev. Plant Biol, Vol. 59, pp. 651-81, doi: 10.1146/annurev. arplant. 59.032607.092911, 2008.
[32] B. T. Yasseen, "An analysis of the effects of salinity on leaf growth in Mexican wheats," Thesis, The University of Leeds, UK, 1983.

[33] G. R. Cramer, and R. S. Nowak, "Supplemental manganese improves the relative growth, net assimilation and photosynthetic rates of salt-stressed barley," Physiol. Plant, vol. 84 (4), pp. 600-605, 1992.

[34] P. Carillo, M. G. Annunziata, G. Pontecorvo, A. Fuggi, and P. Woodrow, "Salinity Stress and Salt Tolerance," In: A. Shanker, (Ed.), Abiotic Stress in Plants - Mechanisms and Adaptations, http://www.intechopen.com/books/abioticstress-in-plantsmechanisms-and-adaptations/salinity-stress-and-salt-tolerance, 2011.

[35] J. T. Prisco, and J. W. O'Leary, "Enhancement of intact bean leaf senescence by $\mathrm{NaCl}$ salinity," Physiol. Plant, vol. 27, pp. 95-100, 1972.

[36] C. Itai, and Y. Vaadia, "Cytokinin activity in water -stressed shoots," Plant Physiol, vol. 47, pp. 87-90, 1971.

[37] M. I. Khan, M. A. Khan, and T. Khizar, "Plant growth regulators from species differing in salt tolerance as affected by soil salinity,” Plant \& Soil, vol. 45, pp. 267-271, 1976.

[38] Y. Guo, and S. Gan, "Leaf senescence: Signals, execution, and regulation," Current Topics in Developmental Biology, vol. 71, pp. 83-112, 2005.

[39] J. P. Vainonen, P. Jaspers, M. Wrzaczek, A. Lamminmäki, R. A. Reddy, L. Vaahtera, M. Brosché, and J. Kangasjärvi, "RCD1-DREB2A interaction in leaf senescence and stress responses in Arabidopsis thaliana," Biochemical Journal, vol. 442 (3), pp. 573-58, 2012.

[40] A. T. Ayoub, "Sodium and cation accumulation by senna (Cassia acutifolia)," J. Exp. Bot, vol. 26, pp. 891-896, 1975.

[41] R. Albert, "Salt regulation in halophytes," Oecologia, vol. 21, pp. $57-71,1975$.

[42] Y. Waisel, "Biology of Halophytes," Academic Press, New York and London, 1972.

[43] M. M. Ludlow, and T. T. Ng, "Water stress suspends leaf ageing," Plant Sci. Lett, vol. 3, pp. 235-240, 1974.

[44] R. Munns, C. J. Brady, and E. W. R. Barlow, "Solute accumulation in the apex and leaves of wheat during water stress,” Aust. J. Plant Physiol, vol. 6, pp. 379-389, 1979.

[45] S. Negrao, S. M. Schmockel, and M. Tester, "Evaluating physiological responses of plants to salinity stress," Annals of Botany, vol. 119, pp. 1-11. doi:10.1093/aob/mcw191, available online at www.aob.oxfordjournals.org, 2017.

[46] S. P. Singh, V. Raval, and M. K. Purohit, "Strategies for the salt tolerance in bacteria and archeae and its implications in developing crops for adverse conditions," In: N. Tuteja, and S. Singh Gill, (Eds.), Plant Acclimation to Environmental Stress, Springer, New York, NY, 2013.

[47] H. J. Kunte, " $\mathrm{K}^{+}$Transport and its role for osmoregulation in a halophilic member of the bacteria domain: Characterization of the $\mathrm{K}^{+}$uptake systems from Halomonas elongate," In: N. Gunde-Cimerman et al. (Eds.), Adaptation to Life at High Salt Concentrations in Archaea, Bacteria, and Eukarya, pp. 287300. Springer, The Netherlands, 2005. 
[48] P. Babu, A. K. Chandel, and O. V. Singh, "Survival mechanisms of extremophiles," In: Extremophiles and Their Applications in Medical Processes. Springer Briefs in Microbiology, Springer, Cham, pp. 9-23, 2015.

[49] P. Shivanand, and G. Mugeraya, "Halophilic bacteria and their compatible solutes-osmoregulation and potential applications," Current Science, vol. 100 (10), pp. 1516-1521, 2011.

[50] https://www.cbd.int/doc/world/qa/qa-nbsap-01-en.pdf.

[51] https://www.cbd.int/doc/world/qa/qa-nbsap-v2-en.pdf.

[52] M. Galun, and J. Garty, "Biological soil crusts of the Middle East," In: J. Belnap, andO. L. Lange, (Eds.), Biological soil crusts: structure, function, and management, Berlin, Springer, pp. 95-106, 2003.

[53] R. Richer, D. Anchassi, I. El-Assaad, M. El-Matbouly, F. Ali, I. Makki, and J. S. Metcalf, "Variation in the coverage of biological soil crusts in the State of Qatar," Journal of Arid Environments, vol. 78, pp. 187-190, 2012.

[54] A. H. Moubasher, and A. A. T. Al-Subai, "Soil fungi in the State of Qatar," The Scientific and Applied Research Council, University of Qatar, pp. 108, 1987.

[55] R. F. Al-Thani, "Survey of macrofungi (including truffles) in Qatar," KBM Journal of Biology, vol.1 (2), pp. 26-29, 2010.

[56] F. I. Khalaf, and A. A. Al-Shuaibi, "Occurrence and characteristics of quaternary calcareous microbiatitic crust in the southern desert in Kuwait, Arabian Gulf," J. Arid Environments, vol. 79, pp. 48-55, 2012.

[57] R. M. M. Abed, A. M. Al-Sadi, M. Al-Shehi, S. Al-Hinai, and M. D. Robinson, "Diversity of free-living and lichenized fungal communities in biological soil crusts of the Sultanate of Oman and their role in improving soil properties," Soil Biology \& Biochemistry, vol. 57, pp. 695-705, 2013.

[58] E. Redfield, S. M. Barns, J. Belnap, L. L. Daane, and C. R. Kuske, "Comparative diversity and composition of cyanobacteria in three predominant soil crusts of the Colorado Plateau," FEMS Microbiol. Ecol, vol. 40, pp. 55-63, 2002.

[59] E. M. M. Abdel-Bari, "Record of a fruiticose lichen Ramalina farinacea (L.) Ach. for Qatar," Qatar University Science Journal, vol. 17 (2), pp. 265-270, 1997.

[60] E. M. M. Abdel-Bari, "Addition to the flora of Qatar," Qatar University Science Journal, vol. 17 (2), pp. 303-312, 1997.

[61] R. F. Al-Thani, and H. A. Al-Meri, "Study of some lichens of Qatar," Atlas Journal of Biology, vol 1 (3), pp. 41- 46, 2011.

[62] C. Hartl, A. R. Schmidt, J. Heinrichs, L. J. Seyfullah, N. Schäfer, C. Gröhn, J. Rikkinen, and U. Kaasalainen, "Lichen preservation in amber: morphology, ultrastructure, chemofossils, and taphonomic alteration," Foss. Rec, vol. 18, pp. 127-135, 2015.

[63] E. M. M. Abdel Bari, "The flora of Qatar, The Dicotyledons, The Monocotyledons, Environmental Studies Centre, Qatar University, Doha, Qatar, Volumes:1-2, pp.700 (Volume 1), pp.199 (Volume 2), 2012.

[64] L. A. Richards, "U. S. Salinity Laboratory Staff, Diagnosis and Improvement of Saline and Alkaline Soils," U. S. Department of Agriculture Hand Book No. 60, P 160, 1954.
[65] M. M. Ashore, "Sabkhas in the peninsula of Qatargeomorphologic and geological and biological studiesUniversity of Qatar," Centre of Documentation and Humanitarian Studies, Doha, Qatar, 1991.

[66] P. L. Nimis, C. Scheidegger, P. A. Wolseley, "Monitoring with Lichens-Monitoring Lichens," Kluwer Academic Publishers, The Netherlands, pp. 1-4, 2002.

[67] J. Nascimbene, P. L. Nimis, and L. Marini, "Testing indicators of epiphytic lichen diversity: a case study in N Italy," Biodivers. Conserv, vol. 16, pp. 3377-3383, 2007.

[68] P. William, "Lichens. The Natural History Museum," London, UK. pp. 112. 2000.

[69] K. Müller, "Pharmaceutically relevant metabolites from lichens," Applied Microbiology and Biotechnology, vol. 56, pp. 9-16. 2002.

[70] M. Bačkor, K. Paulíková, A. Geralská, and R. Davidson, "Monitoring of air pollution in Košice (Eastern Slovakia) using lichens," Polish Journal of Environmental Studies, vol. 12 (2), pp.141-150, 2003.

[71] J. Boustie, and M. Grube, "Lichens-a promising source of bioactive secondary metabolites," Plant Genetic Resources, vol. 3, pp. 273-278, 2005.

[72] M. Melgarejo, O. Sterner, J. Vila-Castro, and P. Mollinedo, "More investigations in potent activity and relationship structure of the Lichen antibiotic (+)- using acid its derivate dibenzoylusnic acid," Revista Boliviana De Quimica, vol. 25 (1), pp. 24-29, 2008.

[73] A. M. Mahasneh, "Bacterial decomposition of Avicennia marina leaf litter from AlKhore (Qatar-Arabian Gulf)," On line Journal of Biological Sciences, vol. 1 (8), pp. 717-719, 2001.

[74] A. M. Mahasneh, "Heterotrophic marine bacteria attached to leaves of Avicennia marina L. along the Qatari coast (Arabian Gulf)," On line Journal of Biological Sciences, vol. 2 (11), pp. 740-743, 2002.

[75] R. F. Al-Thani, and I. A. Mahasneh, "Ecology and distribution of Streptomycets in the soil of Qatar," The Scientific and Applied Research Center (SARC), Qatar University, Doha, Qatar, ISBN: 99921-52-56-7, 2002.

[76] G. M. Fahmy, and R. F. Al-Thani, "Ecology of halophytes and their bacterial inhabitants in the coastal salt marsh of AlDhakhira, Qatar," Environmental Studies Centre (ESC), University of Qatar, P. O. Box: 2713, Doha, Qatar, ISBN: 99921-751-0-9. 2006.

[77] R. F. Al-Thani, "Coliform bacteria of wastewater ponds in Qatar," In: H. A. Abulfatih, R. F. Al-Thani, I. S. Al-Naimi, J. A. Sweeileh, E. A. Elhag, and M. M. Kardousha, Ecology of wastewater ponds in Qatar, Scientific and Applied Research Center (SARC), University of Qatar, Doha, Qatar, pp.129145. 2002.

[78] R. F. Al-Thani, D. A. Abd-El-Haleem, and M. Al- Shammri, "Isolation, biochemical and molecular characterization of 2chlorophenol degrading Bacillus Isolates," Afric. J. Biotec, vol. 6 (23), pp. 2675-2681, 2007.

[79] R. F. Al-Thani, D. A. Abd-El-Haleem, and M. Al-Shammri, "Isolation and characterization of polyaromatic hydrocarbonsdegrading bacteria from different Qatar soils," African J. Micro. Res, vol. 3 (11), pp. 761-766, 2009. 
[80] M. Y. Al-Sulaiti, I. M. Al-Shaikh, B. T. Yasseen, S. Ashraf, and H. M. Hassan, "Ability of Qatar's native plant species to phytoremediate industrial wastewater in an engineered wetland treatment system for beneficial water re-use," Qatar Foundation Annual Research Forum Proceedings, Vol. 2013, EEO 010, DOI: 10.5339/qfarf.2013. EEO-010, Published online: 22 Nov 2013.

[81] B. T. Yasseen, "Phytoremediation of industrial wastewater from oil and gas fields using native plants: The research perspectives in the State of Qatar," Central European Journal of Experimental Biology, vol. 3 (4), pp. 6-23, 2014.

[82] S. Abdul Majid, M. F. Graw, A. D. Chatziefthimiou, H. Nguyen, R. Richer, M. Louge, et al., "Microbial characterization of Qatari Barchan sand dunes," PLoS ONE, vol. $11 \quad$ (9), e0161836. https://doi.org/10.1371/journal.pone.0161836, 2016.

[83] C. Gougoulias, J. M. Clark, L. J. Shaw, "The role of soil microbes in the global carbon cycle: tracking the belowground microbial processing of plant-derived carbon for manipulating carbon dynamics in agricultural systems," J Sci Food Agric, vol. 94 (12), pp. 2362-2371, 2014.

[84] M. Hanin, C. Ebel, M. Ngom, L. Laplaze, and K. Masmoudi, "New insights on plant salt tolerance mechanisms and their potential use for breeding," Frontiers in Plant Sciences, vol. 7, Article 1787, 2016

[85] R. Margesin, and F. Schinner, "Potential of halotolerant and halophilic microorganisms for biotechnology," Extremophiles, vol. 5 (2), pp. 73-83. 2001.

[86] T. P. Makhalanyane, A. Valverde, E. Gunnigle, A. Frossard, J. B. Ramond, and D. A. Cowan, "Microbial ecology of hot desert edaphic systems," FEMS Microbiol. Rev, vol. 39 (2), pp. 203-221, 2015.

[87] J. W. Whitaker, G. A. McConkey, and D. R. Westhead, "The transforme of metabolic genes explored: analysis of the horizontal transfer of enzyme encoding genes in unicellular eukaryotes," Genome Biology, vol. 10 (4), Article R36, 2009.

[88] Z. Yuan, I. S. Druzhinina, J. Labbé, R. Redman, Y. Qin, R. Rodriguez, C. Zhang, G. A. Tuskan, and F. Lin, "Specialized microbiome of a halophyte and its role in helping non-host plants to withstand salinity," Scientific Reports, vol. 6, p. 32467, 2016.

[89] T. A. Huck, N. Porter, M. E. Bushell, "Positive selection of antibiotic-producing soil isolates," Journal of General Microbiology, vol. 137, pp. 2321-2329, 1991.

[90] A. R. Srividya, G. S. Saitha, and B. Suresh, "Study of the soil isolates for antimicrobial activity," Indian J. Pharm Sci, vol. 70 (6), pp. 812-815, 2008.
[91] R. N. Ahmed, A. Sani, A. K. Ajijolakewu, and F. B. Alamu, "Soil screening for antibiotic - producing microorganisms," Advances in Environmental Biology, vol. 7 (1), pp. 7-11, 2013.

[92] A. Bizuye, F. Moges, and B. Andualem, "Isolation and screening of antibiotic producing actinomycetes from soils in Gondar town, North West Ethiopia," Asian Pac J Trop Dis, vol. 3 (5), pp. 375-381, 2013.

[93] J. Wiedenbeck, and F. M. Cohan, "Origins of bacterial diversity through horizontal genetic transfer and adaptation to new ecological niches," FEMS Microbiol Rev, vol. 35, pp. 957-976. 2011.

[94] K. M. Nielsen, "Barriers to horizontal gene transfer by natural transformation in soil bacteria," APMIS, vol. 106, pp. 77-84, 1998.

[95] P. J. Keeling, and J. D. Palmer, "Horizontal gene transfer in eukaryotic evolution," Nature Reviews Genetics, vol. 9, pp. 605-618, 2008.

[96] J. Huang, "Horizontal gene transfer in eukaryotes: The weaklink model," Bioessays, vol. 35 (10), pp. 868-875, 2013.

[97] R. E. Blankenship, "Future perspectives in plant biology early evolution of photosynthesis," Plant Physiol, vol. 154, pp. 434 438, 2010.

[98] R. I. Aminov, "Horizontal gene exchange in environmental microbiota," Frontiers in Microbiology, vol. 2 / Article 158, 2011.

[99] B. Lacroix, and V. Citovsky, "Transfer of DNA from bacteria to eukaryotes," mBio, vol. 7 (4), e00863-16. doi:10.1128/mBio.00863-16. V, 2016.

[100] T. V. Matveeva, and L. A. Lutova, "Horizontal gene transfer from Agrobacterium to plants," Front. Plant Sci, vol. 5, p. 326. doi: 10.3389/fpls.2014.00326, 2014.

[101] https://en.wikipedia.org/wiki/Plant_secondary_metabolism.

[102] https://en.wikipedia.org/wiki/Microbial_metabolism.

[103]H. B. Bode, and R. Müller, "Possibility of bacterial recruitment of plant genes associated with the biosynthesis of secondary metabolites," Plant Physiol, vol. 132, pp. 11531161, 2003.

[104] N. Empadinhas, and M. S. da Costa, "Osmoadaptation mechanisms in prokaryotes: distribution of compatible solutes," International Microbiology, vol. 11, pp. 151-161, 2008.

[105] N. Empadinhas, and M. S. da Costa, "Diversity, distribution and biosynthesis of compatible solutes in prokaryotes," Contributions to Science, vol. 5 (1), pp. 95-105. 2009. 